\title{
Italian Hospitals of the Early Renaissance
}

\section{Hubertus Günther (Universität Züirich)}

Hospitals did not belong to the reception of antiquity during the Renaissance; antique literature barely deals with them, Vitruvius says nothing about them, and no built example was known in the Renaissance. Therefore Alberti touches the subject only incidentally in his architectural treatise. He establishes a certain relationship with antiquity only in connection with the sanctuaries of Aesculapius and Apollo, reporting the records that invalids were brought there in the hope that they would be healed by the god, and indirectly, a propos the imperial baths, describing their functions as if they had been therapeutic baths. ${ }^{1}$

Nevertheless Renaissance architecture began with a hospital. In the middle of the fifteenth century, Giovanni Rucellai specifies, as typical elements of the advent of the modern epoch, churches, palaces and hospitals built in the antique style. ${ }^{2}$ The first of these to be realized was the Ospedale degli Innocenti in Florence (fig. 1-3).

At the end of the Middle Ages, hospitals were status symbols of prospering towns in Italy as well as in other parts of the occident and in the Islamic world. ${ }^{3}$ In the face of the Black Death which afflicted Europe during the fourteenth century they gained in importance. Two-thirds of the Italian population fell victim to the plague. The Renaissance actually began in a time when the plague had lost momentum and the problem arose how to react to the terrible consequences of it.

The Italian hospitals, as Alberti treats them, were asylums for people of all kinds who needed help; the sick, paupers, travellers or abandoned and orphaned children. Hospitals comprised offices for the administration, living space for the staff and service rooms such as kitchens and laundries, their centre was constituted by large halls for the beds with chapels visible from all the beds. The seminal disposition of these halls in the form of a cross was probably invented during the fourteenth century in the Florentine Hospital of S. Maria Nuova. Usually the hospitals had an appearance as modest as monasteries, with simple courtyards like monasteries and façades without much decoration, at the most with porticos which also had practical advantages (as, for example, the Ospedale di S. Matteo, Florence, built between 1385 and the beginning of the fifteenth century). The design was secondary to the practical requisites of ample equipment and good organization.

At the beginning of the Renaissance, Florence and Siena were the leaders in public welfare. Both had many small hospitals, even special orphanages, and also a large central hospital; in Siena, the Ospedale di S. Maria della Scala opposite the facade of the cathedral, and in Florence the Ospedale Nuovo, which was extensively restored in $1334 .{ }^{4}$ Alberti praised the

${ }^{1}$ Alberti 1966, V 8, VIII 10, pp. 366-370, 768-777.

${ }^{2}$ A. Perosa (ed.), Giovanni Rucellai ed il suo zibaldone quaresimale, London, 1960-1981, vol. I, p. 60ff. 3 D. Leistikow, Hospitalbauten in Europa aus zehn Jabrbunderten. Ein Beitrag zur Geschichte des Krankenhausbaues, Ingelheim, 1967; J. D. Thompson and G. Goldin, The Hospital. A social and architectural bistory, New Haven CT, 1975; D. Jetter, Das europäische Hospital. Von der Spätantike bis 1800, Cologne, 1986; M.-L. Windemuth, Das Hospital als Träger der Armenfürsorge im Mittelalter, Stuttgart, 1995; J. Henderson,
The Renaissance hospital. Healing the body and healing the soul, New Haven CT, 2006; Drossbach 2007 (historiography on pp. 9-25).

4 Thompson, Goldin 1975 (note 3), pp. 34-69; $\mathrm{J}$. Henderson, Piety and charity in late medieval Florence, Oxford, 1994; J. Henderson, 'Caring for the poor: commessi and commesse in the hospitals of Renaissance Florence', in: Drossbach 2007, pp. 163-175; M. Heinz, San Giacomo in Augusta in Rom und der Hospitalbau der Renaissance, unpublished PhD dissertation, University of Bonn, 1977, pp. 147ff, $158 \mathrm{ff}$. 


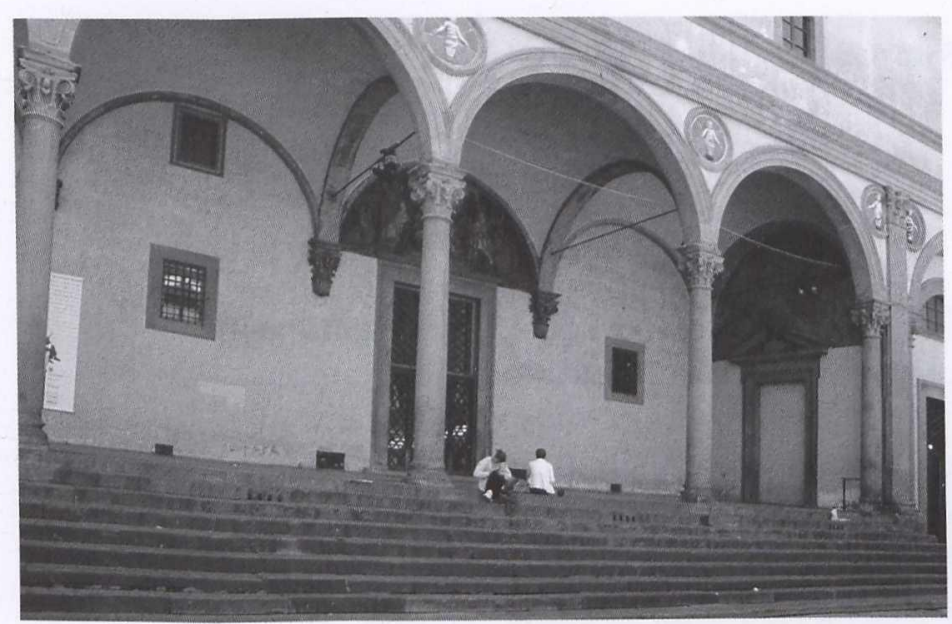

1. Ospedale degli Innocenti, Florence, portico.

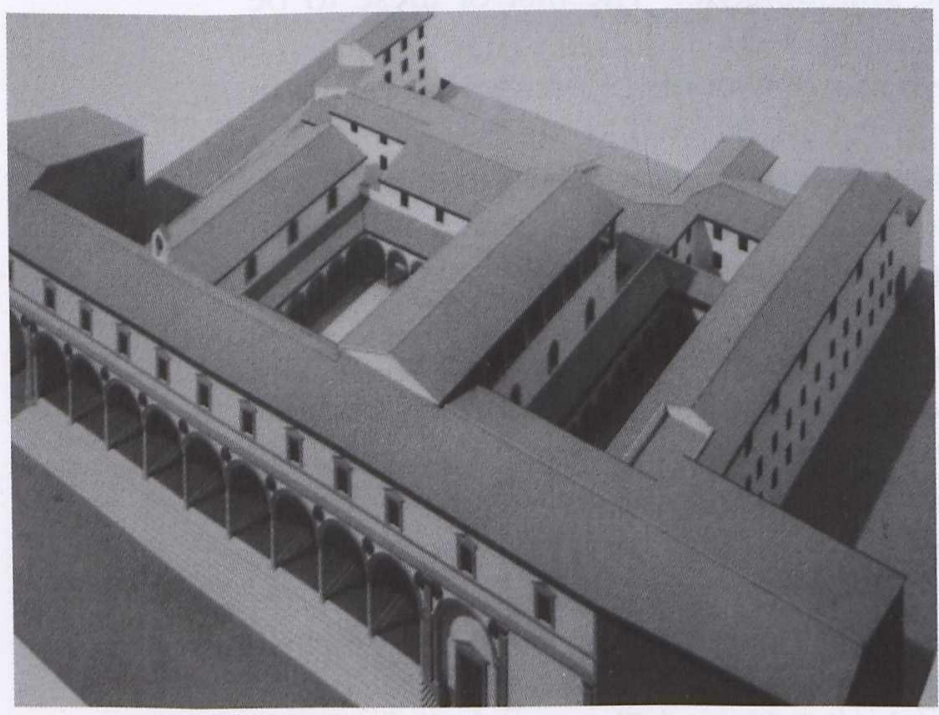

2. Ospedale degli Innocenti, Florence, model, after G. Morozzi. 'marvellous' hospitals in the Toscana, equipped with incredible resources, where every citizen or traveller would find whatever contributed to his health. ${ }^{5}$ A Russian voyager deeply impressed by his visit to Florence (1337-1340) records: "The Hospital of S. Maria Nuova is built, out of Christian charity, for helpless foreigners and pilgrims, even from other countries. Even more, one feeds them, provides them with clothing and shoes and esteems them". He goes on to say that there were more than one thousand beds: "but even on the least bed there are wonderful eiderdowns and expensive blankets". ${ }^{6}$ Martin Luther in 1511 was equally impressed by the comfort and hygiene of the Florentine hospitals. ${ }^{7}$ Already before the advent of the Renaissance outside central Italy, it was reported that even prominent cities which at that time were not orientated towards Tuscany took the hospitals of Florence and Siena as models (e.g. Genoa 1422, Brescia after 1447, Pavia after 1449). ${ }^{8}$ Moreover, the city of Genoa, preparing for the construction of its own hospital, sent engineers to Florence and Siena especially to study the architecture and facilities of the hospitals there.

\section{Ospedale degli Innocenti}

In Florence the municipality had to care for the public welfare. This task was performed not only by the city council, but also by the guilds whose members formed the council, specifically members of the upper guilds which represented wealthy citizens, traders, academics etc., including also people not engaged in manual work and trade, like Dante Alighieri, for example.?

The silk guild, which at the beginning of the Renaissance became one of the leading guilds of Florence, had taken care of orphans since the thirteenth century. In the fourteenth century there were already two asylums for them; in 1419 the silk guild founded a third, then called the Ospedale Nuovo, now the Ospedale degli Innocenti. ${ }^{10}$ It is situated

\footnotetext{
${ }^{5}$ Alberti 1966, V 8, p. 368ff.

${ }^{6}$ G. Stökl, 'Reisebericht eines unbekannten Russen (1437-40)', in: F. Grabler (ed.), Europa im XV. Jahrhundert, von Byzantinern gesehen, Graz, Vienna, and Cologne, 1965, p. 164.

7 M. Luther, Tischreden. Weimarer Ausg. (1916), Tischreden, vol. 4, no. 3930.

${ }^{8}$ Lucio Franchini (ed.), Ospedali lombardi del Quattrocento. Fondazione, trasformazioni, restauri, Como, 1995, pp. 15ff, 20, 119.
}

9 R. Davidsohn, Geschichte von Florenz, vol. 4 part 2, Berlin, 1925, pp. 55-70.

${ }^{10} \mathrm{H}$. Saalman, Filippo Brunelleschi. The buildings, London, 1993, pp. 33-81; L. Sandri (ed.), Gli Innocenti e Firenze nei secoli: un ospedale, un archivio, una città, Florence, 1996. 
north of the cathedral in the newly urbanized region which at this time began greatly to prosper with the rebuilding of the convent of S. Maria dei Servi, now SS. Annunziata. Cosimo de' Medici also erected the new convent of S. Marco nearby and by establishing his famous library there made it a collecting point of the recently discovered antique literature and a centre of Humanism.

The new Ospedale degli Innocenti was appointed to house not only orphans but also children abandoned by their parents, even children born legitimately in wedlock. The support went from nursing babies up to basic education in reading and writing. As Luther

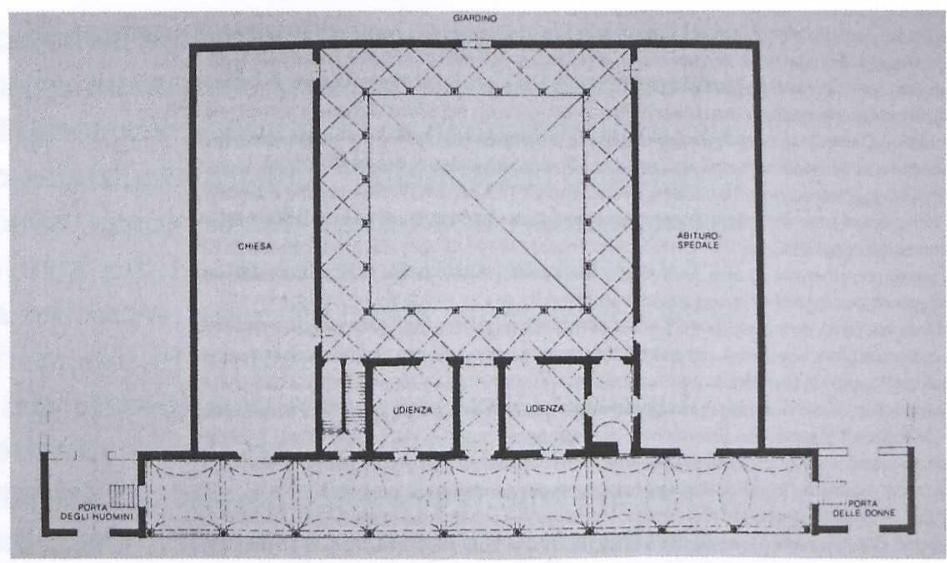

3. Ospedale degli Innocenti, Florence, original project, plan after H. Saalman.

relates, the children were "optimally accommodated, nursed and taught" there. ${ }^{11}$ The boys were dismissed at the age of seven to eight years, but they were not simply abandoned on the street. They were committed to craftsmen, sometimes even being adopted by them, and employed in their workshops or factories. Mainly the silk weavers attended to the apprenticeship of the children.

The silk guild estimated the cost of the new asylum at the enormous sum of 20,000 florins. It was to become their main orphanage and soon was in great demand. At the end of the fifteenth century it housed more than one thousand children and the number increased by almost three hundred children per year. Eight years after the foundation it became necessary to enlarge the hospital; new cellars were excavated even under the already completed structure. The earliest guide to Florence, dating from 1423, that is four years after the foundation of the new orphanage, in describing the hospitals, concentrates on those which were asylums for children, explaining how they worked, giving prominence to the fact that the boys were entrusted to artisans, which is specially noted as a worthy enterprise. The report finishes with the statement that the annual costs of these hospitals equalled those of a whole town. ${ }^{12}$

The silk guild wanted a building which was not only practical, but also beautiful. Indeed a municipal decree of 1421 calls the hospital a "pulcherrimum aedificium". This objective also shows in the choice of Filippo Brunelleschi as architect. Just some months before he received the commission for the Ospedale he had asserted himself with his plan of how to construct the cupola of the cathedral, claiming that architecture should be orientated to antiquity. ${ }^{13}$ Only in this way, he thought, was it possible to solve the urgent problems of the construction, and he recommended himself as the right person for the task by demonstrating intimate knowledge of antique architecture which he, as the first modern architect, had gained by intensive study of Roman ruins. This claim hit the mark of his time.

Some years earlier, the librarian of the Medici, Niccolò Niccoli had begun to study antique architecture. ${ }^{14}$ It was here that the new studies of antique literature pursued by Florentine humanists converged. Florentine intellectuals now claimed generally that one had

11 Luther 1916 (note 7), vol. 4, no. 3930.

${ }^{12}$ C. Gilbert, 'The earliest guide to Florentine architecture, 1423', Mitteilungen des Kunsthistorischen Institutes in Florenz 14, 1969, p. 46.

${ }^{13}$ H. Saalman, Filippo Brunelleschi: The cupola of Santa Maria del Fiore, London, 1980, p. 63; A. Manetti,
The life of Brunelleschi, ed. H. Saalman, London, 1970, pp. 52ff, $64 \mathrm{ff}$.

${ }_{14}$ E. H. Gombrich, 'From the revival of letters to the reform of the arts. Niccolò Niccoli and Filippo Brunelleschi', in: Idem, The Heritage of Apelles. Studies in the Art of the Renaissance, vol. III, Edinburgh, 1976, pp. 93-110. 
to surmount the overall ignorance that prevailed in the occident since the barbarians had destroyed the culture and civilisation of antiquity, and that one should aim for a better future which was again to be guided by reason. In the reign of reason they heralded a revival of culture and civilization. ${ }^{15}$ "How many towns did I see in my youth", Alberti pretended, projecting his utopian hope onto the present, "which had been erected in wood only and now were renewed in marble". ${ }^{16}$ To reach the level of antique civilisation, first it seemed to be necessary to explore what precisely were the achievements of antiquity. On these foundations a new world was to be erected. In this spirit, Marsilio Ficino, Erasmus of Rotterdam and other humanists saw the dawn of a golden age. ${ }^{17}$

Education was considered an essential element in looking back to antiquity, which seems quite reasonable as one aimed for a better future. ${ }^{18}$ There was hardly another field in the early fifteenth century to which as many treatises were dedicated as education. The advance of the Renaissance is connected with the renewal of schooling. In Florence the number of schools of all kinds increased rapidly. ${ }^{19}$ The care for education and of apprenticeship at the Ospedale degli Innocenti was in line with these efforts. Therefore the foundation of the new institution was part of the dawn of the Renaissance.

The architectural structure of the hospital generally was quite commonplace: as usual, it includes a large hall, a chapel and a courtyard on the ground floor. Some years later a second courtyard was added (fig. 2). Offices for the administration and living spaces for the staff were on the upper floor. The utilities, like kitchen, laundry, etc., were probably accommodated in the vaulted cellars. The street façade, as was frequently the case, has a portico and an upper storey with windows. A similar disposition of the ground plan as well as of the façade is still preserved in the hospital of S. Matteo.

The style of the hospital was completely new, however. While the cupola of the cathedral had initially posed mainly technical and organizational problems, the Ospedale degli Innocenti was the first building to be designed in antique style, at least it was the first example of the new style to be visible in a townscape. Originally the disposition of the ground plan was strictly symmetrical, with a central courtyard and two large spaces on either side (fig. 3). The focus of the building's design is the external effect. Its formal highlight is the façade, with Brunelleschi's famous portico (carcass finished in 1424) which was conceived in a style that was most ambitious and conspicuous - ambitious as every detail was deliberately formed in the new manner, and conspicuous as it was obviously out of the ordinary, completely different from the medieval buildings which hitherto were the norm (fig. 1). All elements were taken from the model of antiquity, or at least were thought to be taken from there; moreover the antique models were even 'revised' on the basis of consistent geometrical rules. The façade is not at all ornately decorated, but rather purist, with a dark articulation of pietra serena on a white wall and white vaults

\footnotetext{
15 E. Garin, 'Die Kultur der Renaissance', in: Propyläen Weltgeschichte, vol. VI, ed. G. Mann, A. Nitschke, Frankfurt and Berlin, 1964, pp. 429-534; H. Günther, Was ist Renaissance? Eine Charakteristik der Architektur zu Beginn der Neuzeit. Darmstadt, 2009.

16 Alberti 1966, VIII 5, p. 699

17 Erasmus, letter to Wolfgang Faber Capito von Haguenau, Antwerp, 26 February 1517: M. Ficino, Epistole XI. Opera, Basel, 1576, I, 944; R.A. Mynors and others (transl.), W.K. Ferguson and others (notes), The correspondence of Erasmus (Collected works of Erasmus 1-12), Toronto, Buffalo, 1974-1977, Letter no. 541 .
}

\begin{abstract}
${ }_{18}$ E. Garin, Erziehung Anspruch Wirklichkeit. Geschichte und Dokumente abendländischer Pädagogik, vol II. Humanismus, Reinbek, 1966; P. Grendler, Schooling in Renaissance Italy. Baltimore and London, 1989; G. Müller, Mensch und Bildung im italienischen Renaissance-Humanismus, BadenBaden, 1984.

19 A. Fanfani, 'La préparation intellectuelle et professionelle à l'activité économique en Italie, du XIV au XVI ${ }^{e}$ siècle', Le Moyen Age 57, 1951, pp. 327-346; R. Goldthwaite, 'Schools and teachers of commercial arithmetic in Renaissance Florence', Journal of European Economic History 1, 1972, pp. 418- 433.
\end{abstract}


(the coloured majolica roundels depicting infants were added later, against the will of Brunelleschi). The clearly calculated simplicity represents the conception of reason as the main basis of the new style all'antica. This unique monument is, so to speak, served on a silver platter, or - to paraphrase Filarete - spectacularly staged. The portico rises upon a high socle of steps normally reserved for a few prominent buildings like cathedrals or town halls, where it served for appearances of the public authorities. The steps leading up to the cathedral of Florence and to the town hall were actually lower than those of the Ospedale degli Innocenti.

The architecture of the courtyards, though also built in the new style, is far less elaborated than that of the façade. Vasari ascribes the whole project, the main building as well as the portico, to Brunelleschi. ${ }^{20}$ Antonio Manetti, in his vita of Brunelleschi (c. 1470), only refers to the façade without even mentioning the structures behind it. ${ }^{21} \mathrm{He}$ treats extensively of where the building workers departed from the model of Brunelleschi, commenting on how the enlargement of the hospital affected the façade: "There is also a variation from Filippo's proportions in an addition - besides the error of the addition itself - built on the south side, and appearing on the outside façade of the portico". The practical reasons necessitating the enlargement are not considered as Manetti is generally not interested in the function of the hospital. Obviously, as Machiavelli states, ${ }^{22}$ the outward appearance is as important as what it represents or even more essential. The façade, like a signboard, fulfilled the function of advertising that the silk guild was one of the leaders of the movement towards a better future.

\section{Ospedale Maggiore}

In 1450 Francesco Sforza seized the lordship of Milan after the last duke of the dynasty of the Visconti had died without leaving a legitimate heir and after the 'Ambrosianic republic' led by intellectuals that followed for a short time had failed. The new sovereign introduced the new movement of the Renaissance to Milan. He made it the programme of his regime and he acted like the ideal prince of the rationally-oriented political concept of the Renaissance, which meant preserving and increasing public welfare.

After he had seized power, Francesco proclaimed that he would not govern as a despot but attend to the 'public utility'. He immediately took over the project of the 'Ambrosianic republic' to concentrate the health care system. ${ }^{23}$ The approximately thirty hospitals of the city should be united in a single great institution in order to eliminate the inefficiencies of administration and inconsistent quality. The new central hospital was intended to house 'poor people', as is written above the entrance which meant needy people of many kinds like invalids, paupers and orphans. A convenient site was chosen for it on the bank of the part of the moat that had been made navigable to transport the marble for the cathedral. It was located at the end of the city diametrically opposite the ducal residence, which was rebuilt at the same time.

At first Francesco asked Cosimo de' Medici to recommend an architect for the construction of the hospital, and Cosimo sent Antonio Averlino, afterwards called Il Filarete,

${ }^{20}$ G. Vasari, Le vite de'più eccellenti pittori, scultori ed architettori. Le opere di Giorgio Vasari con nuove annotazioni e commenti, ed. G. Milanesi, Florence, 1906, vol. II, p. 366.

${ }^{21}$ Manetti 1970 (note 13), pp. 94-99.

22 N. Macchiavelli, Il Principe, cap. XVIII.

${ }^{23}$ L. Grassi, Lo "Spedale di poveri" del Filarete. Storia e Restauro, Milan, 1972; R. Quadflieg, Filaretes Ospedale
Maggiore in Mailand. Zur Rezeption islamischen Hospitalwesens in der italienischen Frührenaissance, Cologne, 1981; Patetta 1987, pp. 275-291; E. S. Welch, Art and authority in Renaissance Milan, New Haven CT and London, 1995, pp. 118-166; L. Franchini (ed.), Ospedali lombardi del Quattrocento. Fondazione, trasformazioni, restauri, Como, 1995 , pp. 137-173. 


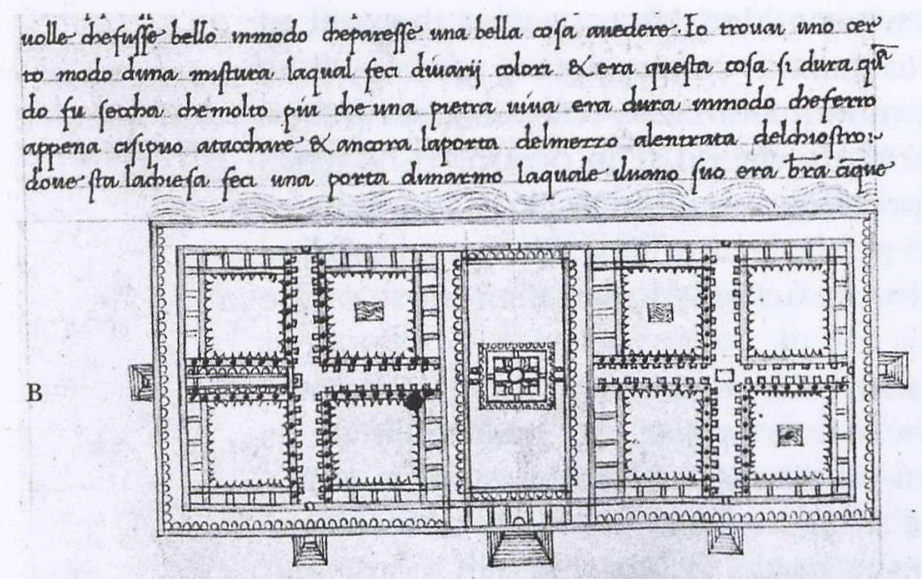

4. Ospedale Maggiore, Milan, plan in the Treatise of Filarete. who brought a plan for the project, as was announced by the Milanese ambassador in Florence. Some years passed before construction began. Then Averlino was sent back to Florence together with an engineer to visit the hospital of S. Maria Nuova there and to draw plans of it. This took place in coordination with the Medici. Giovanni de' Medici wrote to Francesco Sforza that he had shown everything to his architects. The hospital was a worthy thing, he continues, but one should proceed prudently and the designs of several masters were needed. ${ }^{24}$ At the same time events occurred in Mantua that were so similar as if there might have been prior consultation..$^{25}$ There too, the architect for the new central hospital, Luca Fancelli, came from Florence. Ludovico Gonzaga was on good terms with Francesco Sforza; he even participated in the ceremony of laying the foundation stone for the new hospital of Milan.

Francesco wanted the new hospital to be beautiful, suited to the purpose and as orderly as possible. He wanted it to impress the whole world and to be a highlight of his ducal dominion. ${ }^{26}$ Vasari later on attested that the hospital was so well made and so orderly that he believed nothing of the like to exist in the whole of Europe. ${ }^{27}$ Bramante made a plan of the hospital as a model for the government of Venice (1484). ${ }^{28}$ Cesariano even depicted it in his edition of Vitruvius and described it extensively. ${ }^{29}$

The plan was indeed to build the most magnificent hospital that had ever existed: the largest, most elaborate, technically most progressive and most orderly in its disposition. It should consist of three main parts; in the middle a courtyard with a church, and attached to it two side wings each surrounded by porticoes and comprising four courtyards, subdivided by cross-shaped bed halls (fig. 4, 5). This structure was to be situated on a high basement, which included warehouses on the inside and shops on the outside, while on the side facing the city moat, ships could be unloaded so that the material that they brought was directly transported to the warehouses. Under the reign of the Sforza dukes, construction work progressed speedily, thus in the fifteenth century one side wing was finished and the central courtyard begun. The whole project, however, was only finished in the eighteenth century.

The Milanese hospital was beautifully designed but not as uncompromisingly in the modern style as the Ospedale degli Innocenti; the new Forentine style was mainly applied to the inner courtyards (fig. 7). On the outside the decoration was adapted to Milanese tradition including upper-storey windows in the gothic style (fig. 6). In a quite similar way, Filarete designed the branch of the Medici bank in Milan in conformity with the local custom.

The most striking element of the Milanese hospital was not the formal design of the outer appearance, but the practical and technical facilities. Beside every bed was a folding table, which being tipped up, also served as a refuse chute. Between every two beds was a door leading to a lavatory. The lavatories were part of corridors on both sides of the

${ }^{24}$ Patetta 1987, p. 277.

25 Franchini 1995 (note 23), pp. 73-91.

${ }^{26}$ Patetta 1987 , p. 281

27 Vasari 1906 (note 20), vol. II, pp. 456.

\footnotetext{
${ }^{28}$ Patetta 1987, p. 28.

29 Vitruvius, De architectura, ed. C. Cesariano, Como, 1521, ff. 99v, -100 .
} 

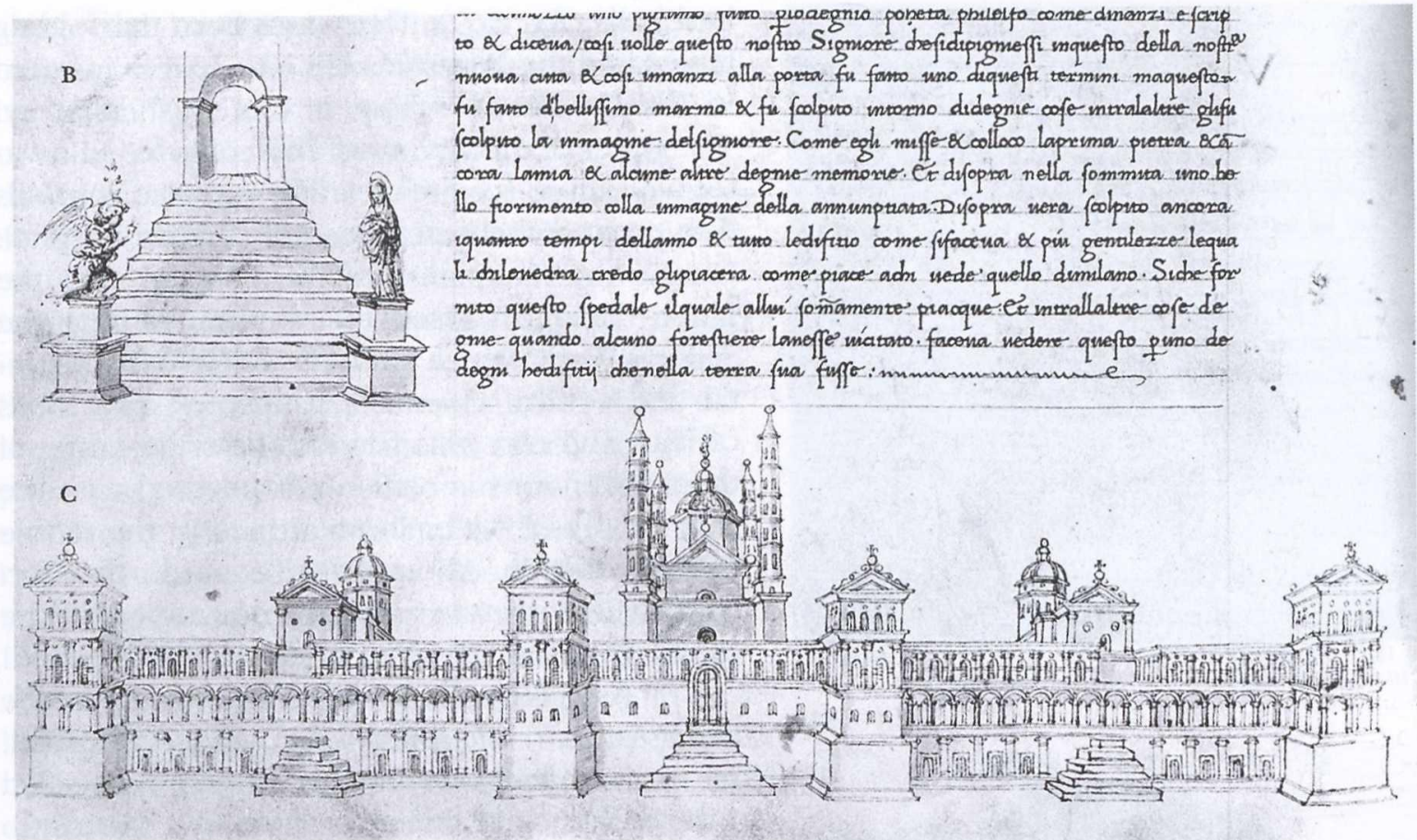

5. Ospedale Maggiore, Milan, elevation in the Treatise of Filarete.

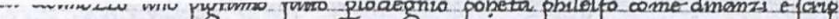

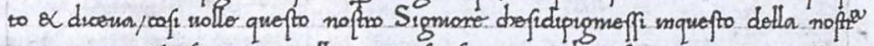

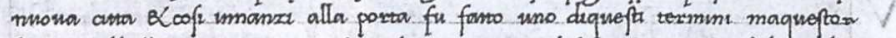

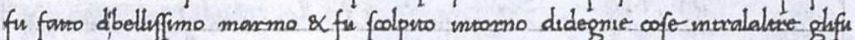
foolpriso la mmagme detfignome: Come egh miffe \&colloco laprima pretca ocecora Lamia ec alame altre depme memorie Et drfopra nella fommita uno bo: the froximento colla umagne detla annumptrata. Difopra nera folpros ancora.

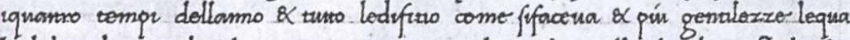
I2 dilonedra exedo olupracera comer prace adr rede' quelto dumilano. Sidhe for

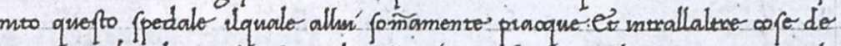

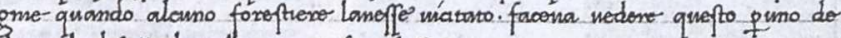

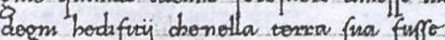

西 aning , 


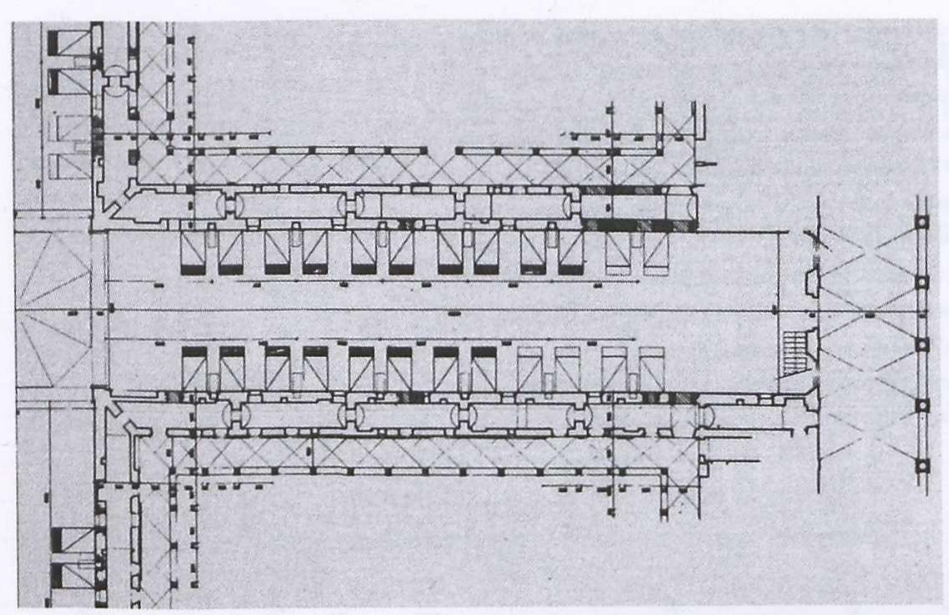

8. Ospedale Maggiore, Milan, plan of one of the old wings showing the corridor of lavatories flanking the hall and reconstruction of the original position of the beds, after $\mathrm{L}$. Franchini.

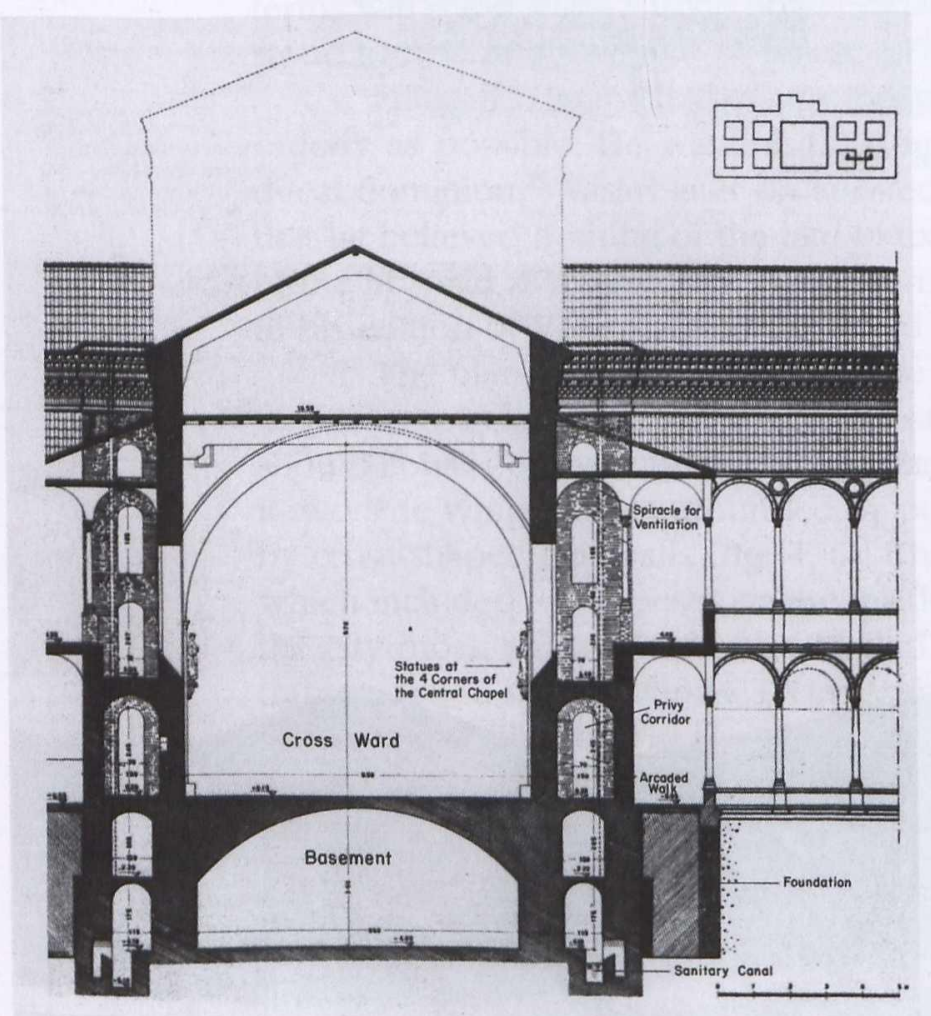

9. Ospedale Maggiore, Milan, section of one of the old wings showing the corridor of lavatories flanking the hall, after $\mathrm{L}$. Grassi and J. D. Thompson.

${ }^{30}$ Leonardo, Ms. B, ff. 38v-39r u. passim. Leonardo architetto e urbanista, ed. Luigi Firpo, Turin, 1971, pp. 88-92.

${ }^{31}$ H. Günther, 'Society in Filarete's "Libro architettonico" between Realism, Ideal, Science Fiction and bed halls (fig. 8, 9). The waste from the folding tables and the lavatories fell into spaces inserted in the basement, where it was washed away. The water of the city moat and collected rainwater were used for the cleaning and also for mills that ground the grain needed for the hospital. During the restoration of the hospital after the grave damage caused by bombing during the Second World War, a complex system of horizontal and vertical channels, gangways, and tubes of lead and clay was found. The wide range of these inventions is certainly connected with the rich supply of water in Milan and in the whole plain of the Po. About 1490 Leonardo da Vinci conceived somewhat similar installations for the cleaning of stables when he lived in Milan. ${ }^{30}$

As in Florence, an important element of the Renaissance in Milan was the humanistic renewal. The famous graecist, Francesco Filelfo, was called to the Sforza court where he formed a friendship with the architect of the hospital, Antonio Averlino, to whom he gave the name Il Filarete, the 'brave' or the 'efficient' one. Filarete, perhaps with his help, wrote an architectural treatise describing the foundation of an ideal city. There he ideates constructions and even social institutions which bear properly utopian traits, such as, and most notably, a school where all kinds of schooling, from elementary education and apprenticeship in the workshops of artisans up to academic studies were united under the same roof. ${ }^{31} \mathrm{He}$ even describes there at length (over some twenty pages) the project of the new hospital of Milan (fig. 4, 5). ${ }^{32}$ The main importance is attached to the technical equipment. Some of the facilities cited above were taken from the indications given there. Filarete is hardly concerned with the decoration and with artistic values. Even where, exceptionally, a sumptuous appearance is planned, as in the case of the central church, he confines himself to scant instructions that it should be covered with coloured stones and mosaics.

In relation to the disposition of the hospital, Filarete even mentions that there were stairs leading up from the ground to the entrances

Utopia', in: B. Hub (ed.), Arte Lombarda 155, 2009, 1 (Architettura e Umanesimo. Nuovi studi su Filarete), pp. 56-80.

32 A. Averlino detto il Filarete, Trattato di architettura, ed. A.M. Finoli and L. Grassi, Milan, 1972, pp. 299-322. 
above the basement, adding peculiar supplementary advice on how the stairs should not be made. ${ }^{33}$ Filarete is opposed to the opinion of some people that they should be as wide as the whole length of the hospital. For many reasons he prefers them to be no broader than the entrance, mainly for utility, as this is more economical and makes it possible to insert shops in the basement. Secondly he points out that there is no need for large stairs, as the façade of the hospital was not a place for spectacles. The patron approves the opinion of his architect, confirming that this was not a theatre where one stays to see festivities. This differentiation is obviously directed against the Ospedale degli Innocenti, implying that such an institution, although a herald of the Renaissance, would be better advised to have perfect technical equipment than a spectacular appearance.

\section{Ospedale S. Spirito}

As a result of the exile of the papal curia in Avignon, the great papal schism and the expulsion of Pope Eugene IV, the city of Rome had degenerated to such an extent that the king of Naples, on his visit in the holy year of 1475 , could say to the face of Pope Sixtus IV that a town in such a state could not be governed. The energetic pope managed to turn the miserable situation around, however. He initiated a substantial renewal of the Eternal City which would soon lead to a splendid blossoming under his nephew, Pope Julius II. Sixtus restored the traffic routes, built a new bridge, repaired the churches and founded many new

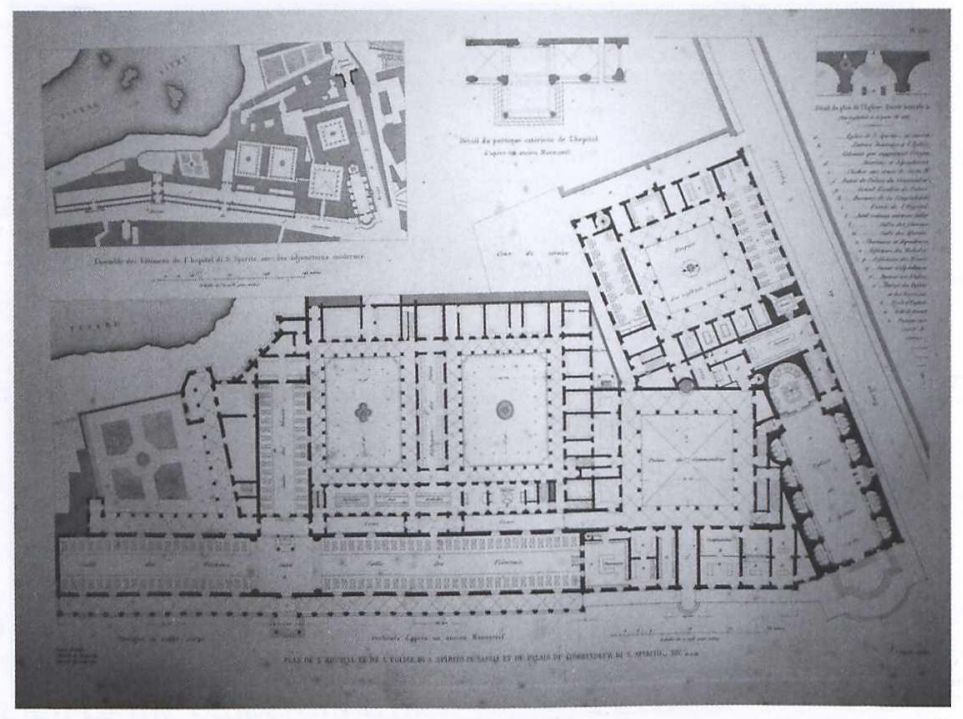

10. Ospedale di S.Spirito, Rome, plan, after P. Letarouilly (1860).

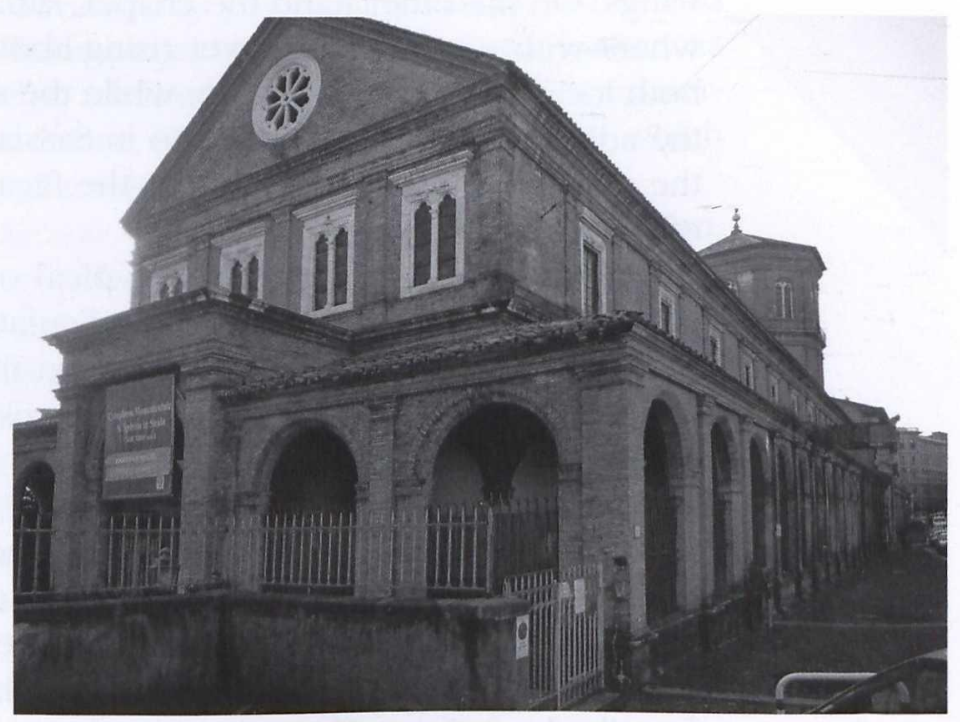

11. Ospedale di S.Spirito, Rome, view on the sides going to Ponte S. Angelo and to the street leading to St. Peter's. ones, and these initiatives caused a great boom of private building activities and generally of the economy. ${ }^{34}$ Sixtus was guided more by the ideal of poverty propagated by the Franciscan Order, whose general he had been, than by a sense of splendour. Simplicity and functionality are typical of the style of most of his buildings. The most magnificent monument of his attitude was the Ospedale di S. Spirito which he had rebuilt in only five years after the old structure had burnt down (fig. 10, 11). ${ }^{35}$

\footnotetext{
33 Averlino detto il Filarete 1972 (note 32), p. $306 \mathrm{ff}$.

${ }^{34}$ F. Benzi, Sisto IV renovator urbis, Roma, 1990.

35 P. de Angelis, L'Ospedale di S. Spirito in Sassia, Rome, 1960-1962; E.D. Howe, The hospital of Santo Spirito and Pope Sixtus IV, New York and London, 1978; Benzi 1990 (note 34), pp. 124-134; A. Esposito, 'Von der GastfreundschaftzurKrankenaufnahme:zurEntwicklung
}

und Organisation des Hospitalwesens in Rom im Mittelalter und in der Renaissance', in: M. Matheus (ed.), Funktions- und Strukturwandel spätmittelalterlicher Hospitäler im europäischen Vergleich, Stuttgart, 2005, pp. 15-28; A. Rehberg, 'Die Römer und ihre Hospitäler', in: Drossbach 2007, pp. 225-260. 


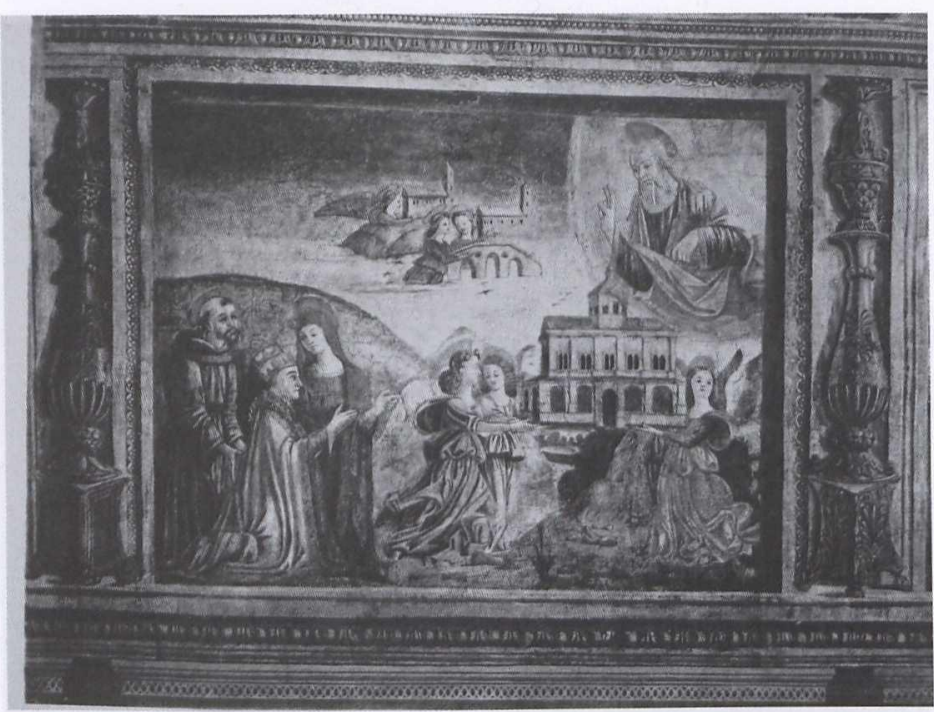

12. Sixtus IV presents his buildings to God, anonymous fresco in the Ospedale di S. Spirito, Rome.
The Ospedale di S. Spirito, like most contemporary hospitals, was destined to house needy people of many kinds, even pilgrims, and it comprised a large separate section for orphans with its own courtyard. Exceptionally, there was even a section for noble invalids. At the time when it was finished, the hospital may have been the largest one in Christendom. The biographer of the pope, the humanist Platina, relates that many architects were consulted for its construction, just as Giovanni de' Medici had advised to Francesco Sforza with respect to the Milanese hospital. The disposition is not as regular as that of the Milanese example and of some other hospitals by then under construction. It was adapted to the site between the banks of the Tiber and the street leading to St Peter's. Therefore the hall of the beds has only three wings. On the other hand the chapel, situated in the crossing, is more accentuated than elsewhere with a prominent tower rising above it. The two courtyards, for men and women, are both located on the same side, while the section of the orphans is somewhat remote, behind the adjoining church of S. Spirito in Sassia. Outer porticoes cover the building on the side of the street leading to St Peter's, at the façade opposite the Ponte S. Angelo, and at a portion of the façade opposite the Tiber.

The style is simple, as is typical of the buildings of Sixtus IV. On the exterior brick work, there is a restrained Doric articulation and windows with gothic elements, generally similar to the Milanese hospital, and in the courtyards Ionic and Corinthian columns. Only the interior of the tower above the crossing, a shelter for the altarpiece, is sumptuously adorned in the antique style.

The hall with the beds is decorated with frescoes which depict the lives of the founders, Alexander III and Sixtus IV. At the end, the cycle of Sixtus shows what the pope had done to renew the city. He presents his buildings to God: the Sistine bridge, two churches standing for many of them and most prominent, in the foreground, the hospital (fig. 12). The next fresco shows, as the effect of this presentation, Sixtus in reward for his good deeds being received in paradise by St Peter. The style of the frescoes is as simple as their content. The painter is anonymous. A similar plain, even vulgar, style of language is typical for the many inscriptions which were placed in Rome to commemorate the urban activities of Sixtus. For example, the largest of these plaques, instead of a eulogy in noble rhetoric as was common, begins: "Thou, Campus Martius, that recently were rotten and dirty from stinking junk and full of nasty mud, under the reign of Sixtus IV abandonst that ugly aspect ..." (Campo de' Fiori). Another style was chosen for a noble ambience. Compare the simple frescoes of the hospital with the marvellous ones which the same pope commissioned from the greatest painters of Italy for the Sistine Chapel.

In the Sistine Chapel, Botticelli has inserted the Ospedale di S. Spirito as the central architectural setting of 'The Temptations of Christ'. Opposite it, he has painted the arch of Constantine in 'The Insurgence against the Laws of Moses' which means there a prefiguration of 'The Temptations of Christ' during the old covenant. ${ }^{36}$ Thus the hospital figures as

${ }^{36}$ L. D. Ettlinger, The Sistine Chapel before Michelangelo, Oxford, 1965; H. W. Pfeiffer, Die Sixtinische Kapelle neu entdeckt, Stuttgart, 2007. 
a modern counterpart to the ancient triumphal arch which commemorates the victory of Constantine under the sign of the cross.

In the panegyrics of Sixtus IV his building activities were compared with those of antiquity. It was claimed that he had ornamented Rome more than any other ruler, but not with triumphal arches and obelisks, baths, naumachias, circuses, theatres and similar buildings; such buildings were said to have been invented more for insane voluptuousness or ambition than to meet real needs. Sixtus was praised for having constructed traffic routes, churches, chapels, monasteries and many other remarkable buildings which were required by utility, piety or honesty and not by pomp and glory. ${ }^{37}$ Later in the sixteenth century, Philibert Delorme would denounce the pyramids of the Egyptian kings in the same spirit as useless and vainglorious, and advise rich people to spend their money on the foundation of hospitals and other public utilities rather than to build magnificent houses which serve just to arouse envy and jealousy..$^{38}$

Criticism of the corrupt morals in antiquity was not new. It is already to be found in the humanistic literature at the very beginning of the Renaissance. ${ }^{39}$ Flavio Biondo and many others criticized the moral decadence during the reign of the emperors which seemed to be a cause for the decline of the empire. As paradigms for such decadence they cited the pyramids which were condemned for having just served to vanity, and vast building complexes such as the imperial baths or the circuses, which were devalued as places of trivial pleasures and pure lust. Alberti's description of the functions of the imperial baths as therapeutic baths was just an attempt to defend the architecture which he so admired against the general moral verdict. Maffeo Vegio in 1457 expressly contrasted the insane lust, dissipation and cruelty which prevailed in the circuses with Christian humility and modesty. ${ }^{40}$

As usual in the Renaissance, even this criticism was based on an antique tradition. Many Roman authors judged the moral value of architecture mainly by the criterion of utility. ${ }^{41}$ Pliny and others denigrated as superfluous and ostentatious such enormous constructions as the Egyptian pyramids and, in Rome, the Golden House of Nero or the theatres. However, the Romans evaluating the utility of architecture had in mind more technical works than humanitarian institutions. ${ }^{42}$ Pliny considered the aqueducts and sewers to form the real essence of architecture and to be the greatest of all the world's wonders. ${ }^{43}$ Cicero thought that utilitarian public buildings such as walls and aqueducts were more to be praised than theatres and even new temples. ${ }^{44}$ Frontinus goes as far as to combine admiration for the advantages of aqueducts with general criticism of the fine arts in Greece: "With such an array of indispensable structures carrying so many waters, compare, if you will, the idle pyramids or the useless, though famous, works of the Greeks". ${ }^{45}$ Thus the Milanese hospital of Filarete, which combined a

37 See for instance Robert Flemmyng, Lucubraciunculae tiburtinae, 1473-1477 (on this source, R. Weiss, Humanism in England during the fifteenth century, 4th [online] ed. D. Rundle and A. J. Lappin, 2009, pp. 157-158, and the literature quoted therein); T. Buddensieg, 'Die Statuenstiftung Sixtus' IV. im Jahre 1471', Römisches Jahrbuch für Kunstgeschichte 20, 1983, p. 55, appendix I.

${ }_{38}$ P. Delorme, Le premier tome de l'arcbitecture, Paris, 1567, ff. 129 v. -130 .

${ }^{39}$ H. Günther, "Insana aedificia thermarum nomine extructa". Die Diokletiansthermen in der Sicht der Renaissance', in: Hülle und Fülle. Festschrift für Tilmann Buddensieg, Alfter, 1993, pp. 251-283.
${ }^{40}$ Maffeo Vegio, De rebus antiquis memorabilibus basilicae S. Petri Romae, in: Acta Sanctorum Junii VII, p. $64 \mathrm{ff}$.

${ }^{41} \mathrm{C}$. Edward, The politics of immorality in ancient Rome, Cambridge, 1993.

${ }^{42}$ H. Günther, 'Umanisti e architetti del primo Rinascimento davanti alle infrastrutture idriche e tecniche dell'antichità romana', Humanistica. An International Journal of Early Renaissance Studies 3, 2008, no. 2, pp. $71-82$.

${ }_{43}$ Plinius, Hist. nat. 36.104; Livius 1.56.2.

${ }^{44}$ Cicero, De officiis 2.60.

45 Frontinus, De aquaeductu 16. 
humanitarian institution with the most advanced technical installations, optimally conformed to the criteria of utility and public welfare from both the antique and the Christian view.

\title{
Conclusion
}

Each of the three preeminent hospitals of the Italian Renaissance signals the start of a new epoch: the dawn of the Renaissance in Florence, the advent of the Renaissance in Milan initiated by Francesco Sforza when he seized power, and the regeneration of the Eternal City under Pope Sixtus IV. The new humanitarian institutions were all destined not only to serve public welfare, but also to demonstrate the honourable intentions of the authorities. The constructions, as well as contemporary commentaries, testify that three different styles of propagating that attitude were chosen. An innovative design, though following purely formal criteria, was exhibited as a symbol of a progressive spirit that enhanced public welfare, or most elaborate techniques which actually surpassed antiquity were employed for the sake of practical utility, or modesty and economic prudence instead of vainglory were advocated as the adequate means of social progress.

\section{Frequently cited works}

\author{
Alberti 1966 \\ L.B. Alberti, De re aedificatoria, ed. G. Orlandi, P. Portoghesi, Milan, 1966. \\ Drossbach 2007 \\ G. Drossbach (ed.), Hospitäler in Mittelalter und früher Neuzeit. Frankreich, Deutschland \\ und Italien. Eine vergleichende Geschichte, Munich, 2007.
}

Patetta 1987

L. Patetta, L'architettura del 400 a Milano, Milan, 1987. 